University of Nebraska - Lincoln

DigitalCommons@University of Nebraska - Lincoln

Faculty Publications in Food Science and Technology

Food Science and Technology Department

3-2007

\title{
Crop Rotation and Soil Amendment Alters Sorghum Grain Quality
}

\author{
Nanga Mady Kaye \\ University of Nebraska-Lincoln \\ Stephen C. Mason \\ University of Nebraska-Lincoln, smason1@unl.edu \\ David S. Jackson \\ University of Nebraska-Lincoln, djackson1@unl.edu \\ Tom D. Galusha \\ University of Nebraska--Lincoln, tgalusha1@unl.edu
}

Follow this and additional works at: https://digitalcommons.unl.edu/foodsciefacpub

Part of the Food Science Commons

Kaye, Nanga Mady; Mason, Stephen C.; Jackson, David S.; and Galusha, Tom D., "Crop Rotation and Soil Amendment Alters Sorghum Grain Quality" (2007). Faculty Publications in Food Science and Technology. 113.

https://digitalcommons.unl.edu/foodsciefacpub/113

This Article is brought to you for free and open access by the Food Science and Technology Department at DigitalCommons@University of Nebraska - Lincoln. It has been accepted for inclusion in Faculty Publications in Food Science and Technology by an authorized administrator of DigitalCommons@University of Nebraska - Lincoln. 


\title{
Crop Rotation and Soil Amendment Alters Sorghum Grain Quality
}

\author{
Nanga Mady Kaye, Stephen C. Mason, „ David S. Jackson, and Tom D. Galusha
}

\begin{abstract}
Soybean [Glycine $\max$ (L.) Merr.] rotation enhances grain sorghum [Sorghum bicolor (L.) Moench] yield, but influence on grain quality has not been measured. The objective was to determine the effect of cropping sequence (CS) and soil amendment (SA) on grain yield and quality. Sorghum grain yield and quality, soil $\mathrm{NO}_{3}-\mathrm{N}$ and water were measured in a rotation study in 2003 and 2004 on a Sharpsburg silty clay loam (fine, smectitic, mesic Typic Argiudoll). Cropping sequences were continuous sorghum, and sorghum rotated with non-nodulating and nodulating soybean. Soil amendments consisted of no amendment, manure (17-26 Mg dry matter ha ${ }^{-1}$ $\left.\mathrm{yr}^{-1}\right)$, and $\mathrm{N}\left(84 \mathrm{~kg} \mathrm{ha}^{-1} \mathrm{yr}^{-1}\right) . \mathrm{CS} \times \mathrm{SA}$ interaction effects were found for most parameters. Rotation with non-nodulating soybean without SA increased yield by 2.6 to $2.8 \mathrm{Mg} \mathrm{ha}^{-1}$ over continuous sorghum without SA. Rotation without SA with nodulating soybean further increased yield by 1.7 to $1.8 \mathrm{Mg} \mathrm{ha}^{-1}$ over rotation with non-nodulating soybean. Grain $\mathrm{N}$ increased by 0.5 to $1.0,2.5$ to 5.0 , and 3.3 to $4.9 \mathrm{~g} \mathrm{~kg}^{-1}$ for $\mathrm{N}$ application to continuous sorghum and sorghum rotated with non-nodulating and nodulating soybean, respectively. Tangential abrasive dehulling device (TADD) removal indicated that continuous sorghum without SA produced the softest grain with 43 to $44 \%$ TADD removal, and sorghum rotated with nodulating soybean with manure produced the hardest grain with 22 to $27 \%$ TADD removal. As food end-use opportunities for sorghum grain evolve, use of crop rotation and SA application will be important to produce grain with desirable quality attributes.
\end{abstract}

Dep. of Agronomy and Horticulture, and Food Science and Technology, Univ. of Nebraska, Lincoln, NE 68583-0915. Paper No. 14668 of the Journal Series of the Nebraska Agric. Res. Div. Research supported by USAID Grant No. DAN 1254-G-0021 through INTSORMIL, the International Sorghum and Millet Collaborative Research Program. Received 25 May 2006. *Corresponding author (smason1@unl.edu).

Abbreviations: CS, cropping sequence; SA, soil amendment;TADD, tangential abrasive dehulling device.

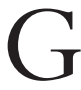
RAIN SORGHUM is an important grain crop in the Central Jreat Plains due to its drought tolerance (Sander and Frank, 1980), high nutrient use efficiency (Maranville et al., 1980), and use for livestock feed. During the past $50 \mathrm{yr}$, sorghum grain yields have increased by $139 \%$ largely due to improved hybrids and soil water management (Unger and Baumhardt, 1999). Due to interest in using sorghum grain for human food (Shayo et al., 2001; Johnson, 2005) and industrial products (Buffo et al., 1998, Johnson, 2005) research efforts are presently underway to develop sorghum hybrids with improved kernel characteristics (Maunder, 2005).

Rotating soybean with sorghum has been shown to increase grain yield (Gakale and Clegg, 1987; Roder et al., 1989a, Peterson and Varvel, 1989), alter soil stored water (Roder et al., 1989a), increase soil N (Bagayoko et al., 1992), improve soil physical properties (Gakale and Clegg, 1987), and reduce yield variability (Varvel, 2000). None of these studies addressed crop rotation or $\mathrm{N}$ supply influences on grain quality. One tool to help separate biologically fixed $\mathrm{N}$ from other rotation effects is the inclusion of nodulating and non-nodulating soybean isolines into a crop rotation as previously done by Maloney et al. (1999), Gentry et al. (2001), and Bergerou et al. (2004).

Manure as a soil amendment in sorghum studies has improved soil physical properties (Eghball, 2000), increased water and

Published in Crop Sci 47:722-729 (2007).

doi: $10.2135 /$ cropsci2006.05.0346

(C) Crop Science Society of America

677 S. Segoe Rd., Madison, WI 53711 USA 
nutrient holding capacity (Sweeten and Mathers, 1985), improved soil nutrient levels (Binder et al., 2002), and increased grain yields (Roder et al., 1989a; Bagayoko et al., 1992). Nitrogen application increases yield by meeting nutrient needs of the crop. The only studies that addressed the influence of manure and $\mathrm{N}$ application on sorghum grain quality have been on $\mathrm{N}$ concentration of grain (Hanson et al., 1988; Kamoshita et al., 1998).

Research on production practice influence on sorghum grain quality is limited. Kamoshita et al. (1998) and Hanson et al. (1988) found increased grain N concentration with increasing levels of $\mathrm{N}$ fertilizer and with rotation with soybean. Similar results have been documented in maize (Kniep and Mason, 1989; Duarte et al., 2005; Shandera et al., 1997) with an associated increase in kernel hardness and decrease in kernel breakage susceptibility with increased N supply. Johnson (2005) found that sorghum grain was harder and had lower starch content when produced under hotter and drier conditions in Texas than in Kansas and Nebraska. He attributed this to starch deposition being restricted when temperatures during grain fill were elevated (Tester and Karkalas, 2001). Other studies have focused on genetic differences influencing grain quality in sorghum (Rooney and Miller, 1982; O'Brien, 1999), especially protein quality (Singh and Axtell, 1973) and digestibility (Oria et al., 2000; Duodu et al., 2003).

The objective of this study was to evaluate rotation with nodulating and non-nodulating soybean isolines and soil amendment application influences on grain yield and quality. An improved understanding of cropping practice influence on sorghum grain quality is important as addedvalue specialty uses for sorghum grain are developed.

\section{MATERIALS AND METHODS}

Research was conducted at the University of Nebraska Agricultural Research Development Center near Mead, NE on a Sharpsburg silty clay loam in 2003 and 2004. The long-term rotation study was established in 1980 and modified in 1991 to incorporate nodulating and non-nodulating isolines of the soybean variety Clark. The experimental factors were cropping sequence and soil amendment. The cropping sequences were continuous sorghum, sorghum-nodulating soybean rotation, and sorghum-non-nodulating soybean rotation. The three soil amendments were zero, fresh beef feedlot manure (17.3 $\mathrm{Mg} \mathrm{ha}^{-1}$ on dry matter basis in 2003 and $25.9 \mathrm{Mg} \mathrm{ha}^{-1}$ in 2004, applied annually in spring, and incorporated by disking), and $84 \mathrm{~kg}$ $\mathrm{N} \mathrm{ha}^{-1} \mathrm{yr}^{-1}$ for sorghum and $41 \mathrm{~kg} \mathrm{~N} \mathrm{ha}^{-1} \mathrm{yr}^{-1}$ for the previous soybean crop. Nitrogen was hand-applied as $\mathrm{NH}_{4} \mathrm{NO}_{3}$ at the $\mathrm{V} 6$ stage growth, which corresponds to the beginning of the stage of rapid sorghum growth and $\mathrm{N}$ uptake (Vanderlip, 1993).

The experiment was conducted in a randomized complete block design with a split-plot treatment arrangement and four replicates. The whole plot was cropping sequence while the subplot was soil amendment. The experimental units were 9.1 $\mathrm{m}$ wide and $7.9 \mathrm{~m}$ long. For weed control, Dual-II Magnum (S-metolachlor: (1S)-2-chloro-N-(2-ethyl-6-methylphenyl)-
$\mathrm{N}$-(2-methoxy-1-methylethyl)acetamide) was sprayed as a preemergent at a rate of $1.1 \mathrm{~kg}$ a.i. ha ${ }^{-1}$, Basagran [bentazon; 3-(1-methylethyl)-1H-2,1,3-benzonthiadiazin-4(3H)-one 2,2dioxide)] at a rate of $1.1 \mathrm{~kg}$ a.i. $\mathrm{ha}^{-1}$ was applied postemergence and by hand weeding. In 2003 during grain-fill, grasshoppers [Melanoplus differentialis (Thomas)] were controlled by aerial application of Lorsban (chlorpyrifos: O,O-diethyl O-(3,5,6trichloro-2-pyridinyl) phosphorothioate) at $0.11 \mathrm{~kg}$ a.i. $\mathrm{ha}^{-1}$

The drought and lodging-tolerant sorghum hybrid DKS4220 , with 105- to $110-\mathrm{d}$ relative maturity and intermediate staygreen was planted in both years. Previous crop soybean variety was Clark with a group IV maturity classification and indeterminate growth habit. Tillage consisted of disking on 21 May 2003 and 27 May 2004. Crops were planted on 22 May 2003 and 27 May 2004 using a six-row John Deere 7100 maxi-merge planter (John Deere, Moline, IL) at the rate of 39285 kernels $\mathrm{ha}^{-1}$ in 2003 and 32190 kernels ha ${ }^{-1}$ in 2004.

\section{Soil $\mathrm{NO}_{3}-$ Nitrogen and Water}

Soils were sampled to a depth of $120 \mathrm{~cm}$ at planting, V6, anthesis and physiological maturity for determining soil $\mathrm{NO}_{3}-\mathrm{N}$. Two soil cores for each plot were gathered using Giddings Soil probe (Fort Collins, CO) and composited. Soil samples were analyzed for soil $\mathrm{NO}_{3}-\mathrm{N}$ using the automated $\mathrm{Cd}$ reduction method analyzed by flow injection analysis (Gelderman and Beegle, 1998). Soil water was determined as the difference in soil weight at sampling, and after being oven drying at $45^{\circ} \mathrm{C}$ until a constant weight was reached. Treatment influences on soil $\mathrm{NO}_{3}-\mathrm{N}$ and water were presented in Kaye et al. (2007), while correlations between these soil and grain quality parameters are presented in this article.

\section{Sorghum Grain Harvest and Quality Assessment}

Grain yields were hand-harvested from an area of $9 \mathrm{~m}^{2}$ in the middle of each 12-row ( 8 by $9 \mathrm{~m}$ ) plot, and were corrected to $140 \mathrm{~g} \mathrm{~kg}^{-1}$ water content. Panicles from the harvest area were threshed, and approximately $500 \mathrm{-g}$ grain samples were collected and used for grain quality assessment tests. Quality parameters measured included kernel weight determined by weighing 100 kernels in duplicates, $\mathrm{N}$ concentration determined by Dumas method (Padmore, 1990), bulk density (test weight), true density measured on 20 -g samples using a multipycnometer (Quantachrome Instruments, Boyntown Beach, FL) and TADD as recommended by Shandera et al. (1997) for maize. For the TADD test, $40 \mathrm{~g}$ of samples were allowed to mill for $4 \mathrm{~min}$ in the TADD machine equipped with an 80 grit abrasive pad (Model 4E-220, Venables Machine Works Saskatoon, Saskatoon, SK) and removal percentage was measured. High bulk and true densities, and low TADD removal indicated hard kernels desirable for dry milling and alkaline-cooked food uses (Mason and D'Croz-Mason, 2002; Shandera et al., 1997).

\section{Scanning Electron \\ Microscopy of Sorghum Kernels}

Sorghum samples were selected based on the kernel hardness measures and grouped into soft and hard samples. Sorghum kernels were cut longitudinally with an industrial razor. Three 
seeds of each sample were mounted on a stub using double sticky stickers and coated with gold-palladium $(\approx 20-n m$ thickness) using Hummer sputter coating equipment (Anatech Ltd., Union City, CA). The samples were observed under scanning electron microscope (Hitachi S-3000N). Pictures were captured by automatic image capturing software (Hitachi Science Systems LTD., Schaumburg, IL). Magnifications and linear scale are indicated in the micrographs.

\section{Statistical Analysis}

Data were analyzed by ANOVA, appropriate orthogonal contrasts using SAS proc mixed procedures (Littell et al., 1996). All factors were considered fixed except replication, and $P$ $\leq 0.05$ was used to declare significant differences. Pearson correlations were calculated to determine the relationship between grain quality parameters and grain yield, and soil $\mathrm{NO}_{3}-\mathrm{N}$ and water content. Hartley's F-max test for homogeneity of variance (Dowdy and Wearden, 1991) indicated lack of homogeneity of variance $(P \leq 0.05)$ for all parameters measured except kernel weight and TADD removal, thus years were analyzed separately.

\section{RESULTS AND DISCUSSION}

\section{Climate, Soil, Manure, and Previous Crop}

Growing season precipitation in 2003 was $298 \mathrm{~mm}$ and in 2004 was $342 \mathrm{~mm}$, both well below the $480 \mathrm{~mm} \mathrm{30-yr}$ average precipitation for Mead, NE. Precipitation in 2004 was better distributed during the growing season than in 2003. Average growing season temperatures were similar, but it was $3^{\circ} \mathrm{C}$ hotter during July and August 2003 than in 2004. In 2004, temperatures were higher in May and September, which is important given sorghum's base temperature of $15^{\circ} \mathrm{C}$ (Kasalu et al., 1993), and early and late season sensitivity to cold temperature (Eastin, 1976). Both years had temperatures lower than the 30-yr average.

Soil test results indicated that the 23-yr cropping sequence on the experimental site had no effect on soil nutrient levels and organic matter concentration (data not presented), while manured plots had 1 to $3 \mathrm{~g} \mathrm{~kg}^{-1}$ higher organic matter concentration, 0.2 to 0.5 higher $\mathrm{pH}, 80$ to $100 \mathrm{~g} \mathrm{~kg}^{-1}$ higher $\mathrm{P}$, and 300 to $375 \mathrm{~g} \mathrm{~kg}^{-1}$ higher K. Soil nutrient levels for all plots were greater than the sufficiency level for grain sorghum production (Ferguson, 2000).

Manure application and nutrient concentrations were greater in 2003 than in 2004. Manure application in 2003 contained $196 \mathrm{~kg} \mathrm{ha}^{-1}$ total N, $93 \mathrm{~kg} \mathrm{ha}^{-1} \mathrm{P}$, and $225 \mathrm{~kg} \mathrm{ha}^{-1}$ $\mathrm{K}$, while in $2004,378 \mathrm{~kg} \mathrm{ha}^{-1}$ total $\mathrm{N}, 458 \mathrm{~kg} \mathrm{ha}^{-1} \mathrm{P}$, and 448 $\mathrm{kg} \mathrm{ha}{ }^{-1} \mathrm{~K}$ were applied. Manure contribution to inorganic soil $\mathrm{N}$ during the first, second, and third year of application has been documented by Bagayoko et al. (1992) while recent estimates indicates that $25 \%$ of solid beef feedlot $\mathrm{N}$ becomes available during the first growing season after application (DeLoughery and Wortmann, 2003). Previous soybean crop yields were sufficient to give a $50 \mathrm{~kg} \mathrm{ha}^{-1} \mathrm{~N}$ credit to the succeeding sorghum crop (Ferguson, 2000; Bundy, 2003).

\section{Soil $\mathrm{NO}_{3}-$ Nitrogen and Water}

Across cropping sequences, manured plots had the highest average soil $\mathrm{NO}_{3}-\mathrm{N}$ level of $134 \mathrm{~kg} \mathrm{ha}^{-1}$ in 2003 and $161 \mathrm{~kg} \mathrm{ha}^{-1}$ at the $\mathrm{V} 6$ growth stage, while the zero soil amendment had the lowest average soil $\mathrm{NO}_{3}-\mathrm{N}$ of $49 \mathrm{~kg}$ $\mathrm{ha}^{-1}$ in 2003 and $35 \mathrm{~kg} \mathrm{ha}^{-1}$ in 2004 (Kaye et al., 2007). These differences were consistent with the 112 to $250 \mathrm{~kg}$ $\mathrm{ha}^{-1}$ larger $\mathrm{N}$ application with manure than $\mathrm{N}$ fertilizer, and higher soil organic matter content in manured plots. The highest soil $\mathrm{NO}_{3}-\mathrm{N}$ levels at the $\mathrm{V} 6$ growth stage of $118 \mathrm{~kg} \mathrm{ha}^{-1}$ in 2003 and $139 \mathrm{~kg} \mathrm{ha}^{-1}$ in 2004 were found in the rotation with nodulating soybean, intermediate of 95 $\mathrm{kg} \mathrm{ha}^{-1}$ in 2003 and $109 \mathrm{~kg} \mathrm{ha}^{-1}$ in 2004 for rotation with non-nodulating soybean, and lowest of $61 \mathrm{~kg} \mathrm{ha}^{-1}$ in 2003 and $72 \mathrm{~kg} \mathrm{ha}^{-1}$ in 2004 in continuous sorghum similar to those reported by Gentry et al. (2001).

Volumetric soil water content was similar for all treatments at planting, while differences were present at the V6 and anthesis growth stages due to differential transpiration use of water by sorghum (Kaye et al., 2007). At anthesis, continuous sorghum without soil amendment had the greatest volumetric soil water content of $111 \mathrm{~cm}^{3}$ $\mathrm{cm}^{-3}$ in 2003 and $121 \mathrm{~cm}^{3} \mathrm{~cm}^{-3}$ in 2004 , continuous sorghum with soil amendment had intermediate volumetric soil water content of 91 to $98 \mathrm{~cm}^{3} \mathrm{~cm}^{-3}$ in 2003 and 108 to $112 \mathrm{~cm}^{3} \mathrm{~cm}^{-3}$ in 2004 , and rotated sorghum with soil amendment application had lowest volumetric soil water content of 87 to $89 \mathrm{~cm}^{3} \mathrm{~cm}^{-3}$ in 2003 and 102 to $107 \mathrm{~cm}^{3}$ $\mathrm{cm}^{-3}$ in 2003 .

\section{Grain Yield}

Analysis of variance indicated that sorghum grain yield was influenced by the cropping sequence $\times$ fertilizer interaction effects in both years (Tables 1 and 2). Without soil amendment, including non-nodulating soybean in the cropping sequence increased sorghum grain yield by $143 \%$ in 2003 and $79 \%$ in 2004 over continuous sorghum. In both years, including nodulating soybean in the rotational cropping sequence without soil amendment increased yield by $31 \%$ over rotation with non-nodulating soybean. These data suggest that biological $\mathrm{N}$ fixation effects of soybean accounted for approximately $35 \%$ of the grain yield enhancement due to rotation in 2003 and 41\% in 2004 similar to those reported by Gentry et al. (2001) and Bergerou et al. (2004) for a maize-soybean rotation.

In both years, manure and $\mathrm{N}$ fertilizer had a similar effect on sorghum grain yield (Tables 1 and 2). In the drier 2003 year (Table 1), when $\mathrm{N}$ fertilizer or manure was applied, rotation with non-nodulating soybean increased grain yield by 27 to $29 \%$ with no further increase with rotation of nodulating soybean (Table 1). In 2004, the yield enhancement due to rotation with non-nodulating soybean with $\mathrm{N}$ or manure was $\leq 9 \%$, and further yield increase of rotation with nodulating soybean of $\leq 7 \%$. 
Table 1. Cropping sequence and soil amendment effects on sorghum grain yield and quality in 2003, Mead, NE.

\begin{tabular}{|c|c|c|c|c|c|c|c|}
\hline Cropping sequence & $\begin{array}{c}\text { Soil } \\
\text { amendment }\end{array}$ & $\begin{array}{l}\text { Grain } \\
\text { yield }\end{array}$ & $\begin{array}{c}\text { 100-kernel } \\
\text { weight }\end{array}$ & $\begin{array}{c}\text { Test } \\
\text { weight }\end{array}$ & $\begin{array}{c}\text { True } \\
\text { density }\end{array}$ & $\mathrm{TADD}^{\dagger}$ & $\begin{array}{c}\text { Grain } \\
\mathrm{N}\end{array}$ \\
\hline & & $\mathrm{Mg} \mathrm{ha}^{-1}$ & $g$ & $\mathrm{~kg} \mathrm{~L}^{-1}$ & $\mathrm{~g} \mathrm{~cm}^{-3}$ & $\%$ removal & $\mathrm{g} \mathrm{kg}^{-1}$ \\
\hline \multirow[t]{4}{*}{ Continuous sorghum } & Zero & 2.1 & 2.32 & 0.73 & 1.333 & 43 & 10.4 \\
\hline & N & 5.8 & 2.40 & 0.78 & 1.348 & 33 & 10.9 \\
\hline & $\underline{\text { Manure }}$ & $\underline{6.2}$ & $\underline{2.42}$ & $\underline{0.79}$ & $\underline{1.358}$ & $\underline{33}$ & $\underline{10.9}$ \\
\hline & Mean & 4.7 & 2.38 & 0.77 & 1.346 & 37 & 10.7 \\
\hline \multirow[t]{4}{*}{ Sorghum following non-nodulating soybean } & Zero & 5.1 & 2.34 & 0.77 & 1.340 & 39 & 8.3 \\
\hline & N & 7.5 & 2.34 & 0.78 & 1.360 & 30 & 10.2 \\
\hline & Manure & $\underline{7.9}$ & $\underline{2.45}$ & $\underline{0.78}$ & $\underline{1.355}$ & $\underline{28}$ & $\underline{13.0}$ \\
\hline & Mean & 6.8 & 2.38 & 0.78 & 1.352 & 32 & 10.5 \\
\hline \multirow[t]{5}{*}{ Sorghum following nodulating soybean } & Zero & 6.7 & 2.32 & 0.77 & 1.348 & 34 & 8.9 \\
\hline & $\mathrm{N}$ & 7.2 & 2.05 & 0.78 & 1.340 & 31 & 13.8 \\
\hline & $\underline{\text { Manure }}$ & $\underline{7.3}$ & $\underline{2.35}$ & $\underline{0.78}$ & $\underline{1.350}$ & $\underline{27}$ & $\underline{14.8}$ \\
\hline & Mean & 7.1 & 2.24 & 0.78 & 1.346 & 31 & 12.5 \\
\hline & \multicolumn{7}{|c|}{$F$ test and contrast probabilities $(P>F)$} \\
\hline \multicolumn{2}{|l|}{ Cropping sequence (CS) } & $<0.01$ & 0.39 & 0.10 & 0.35 & 0.02 & 0.16 \\
\hline \multicolumn{5}{|l|}{ Rotation vs. continuous } & \multicolumn{3}{|c|}{$<0.01$} \\
\hline \multicolumn{5}{|l|}{ Nodulating vs. non-nodulating rotation } & \multicolumn{3}{|c|}{0.43} \\
\hline \multicolumn{2}{|l|}{ Soil amendment (SA) } & $<0.01$ & 0.02 & $<0.01$ & $<0.01$ & $<0.01$ & $<0.01$ \\
\hline \multicolumn{2}{|l|}{ Zero vs. amendment } & & & & & $<0.01$ & \\
\hline \multicolumn{2}{|l|}{$\mathrm{N}$ vs. manure } & & & & & 0.07 & \\
\hline \multicolumn{2}{|l|}{$\mathrm{CS} \times \mathrm{SA}$} & $<0.01$ & 0.04 & 0.00 & 0.01 & 0.06 & $<0.01$ \\
\hline \multicolumn{2}{|l|}{ Rotation-continuous vs. zero-amendment } & $<0.01$ & 0.15 & $<0.01$ & 0.05 & & $<0.01$ \\
\hline \multicolumn{2}{|l|}{ Rotation-continuous vs. N-manure } & 0.75 & 0.07 & 0.83 & 0.30 & & 0.14 \\
\hline \multicolumn{2}{|c|}{ Rotation nodulating-rotation nonnodulating vs. zero-amendment } & $<0.01$ & 0.10 & 0.83 & 0.01 & & 0.04 \\
\hline \multicolumn{2}{|c|}{ Rotation nodulating-rotation nonnodulating vs. N-manure } & 0.73 & 0.09 & 0.99 & 0.08 & & 0.20 \\
\hline \multicolumn{2}{|c|}{ MSE (CS) } & 0.77 & 0.07 & 0.0001 & 0.0001 & 14.8 & 5.04 \\
\hline \multicolumn{2}{|l|}{ MSE (residual) } & 0.50 & 0.01 & 0.0002 & 0.00007 & 5.50 & 1.77 \\
\hline
\end{tabular}

†TADD, tangential abrasive dehulling device.

Application of $\mathrm{N}$ or manure resulted in a larger grain yield increase of 4 to $5 \mathrm{Mg} \mathrm{ha}^{-1}$ for continuous sorghum, intermediate increase of $2.6 \mathrm{Mg} \mathrm{ha}^{-1}$ in 2003 and $3.3 \mathrm{Mg} \mathrm{ha}^{-1}$ in 2004 for sorghum following non-nodulating soybean, and smaller increase yield of $0.5 \mathrm{Mg} \mathrm{ha}^{-1}$ in 2003 and $1.8 \mathrm{Mg} \mathrm{ha}^{-1}$ in 2004 for sorghum following nodulating soybean. Roder et al. (1989b) and Bagayoko et al. (1992) reported a similar trend in grain sorghum yield increase due to application of manure and $\mathrm{N}$ for continuous sorghum and sorghum rotated with nodulated soybean.

\section{Grain Quality}

Cropping sequence $\times$ soil amendment interaction effects were found for grain $\mathrm{N}$ concentration, test weight, and true density in both years, but not for TADD removal (Tables 1 and 2). Contrast comparisons indicated no differences in grain quality between rotation with nodulating and non-nodulating soybean, or between $\mathrm{N}$ and manure application for all quality parameters except true density in 2003 and grain $\mathrm{N}$ in both years. In 2003, contrast comparisons for kernel weight did not clearly indicate the basis for the cropping sequence $\times$ soil amendment interaction as none of them were declared significant at $P \leq 0.05$ (Table 1) while in 2004 differences were attributed to application of soil amendment.

Differences in test weight and true density were small in both years (Tables 1 and 2). In both years, test weights were similar for all treatments except for grain produced with continuous sorghum without soil amendment where the test weight was 0.4 to $0.6 \mathrm{~kg} \mathrm{~L}^{-1}$ lower in 2003 and 0.3 to $0.4 \mathrm{~kg} \mathrm{~L}^{-1}$ in 2004 . The same trend was present for true density with the continuous sorghum without soil amendment application having 0.007 to $0.027 \mathrm{~g} \mathrm{~cm}^{3}$ lower density in 2003 and 0.035 to $0.038 \mathrm{~g} \mathrm{~cm}^{3}$ lower density in 2004. Although the contrast comparison was declared significant in 2003, the differences in true density between the rotation with nodulating and non-nodulating soybean vs. $\mathrm{N}$ and manure application was small and of little practical importance.

In contrast to test weight and true density, TADD removal differences were much larger, with no cropping sequence $\times$ soil amendment interaction (Tables 1 and 2). Contrast comparisons indicate that rotation of sorghum with either nodulating or non-nodulating soybean reduced the 
Table 2. Cropping sequence and soil amendment effects on sorghum grain yield and quality in 2004, Mead, NE.

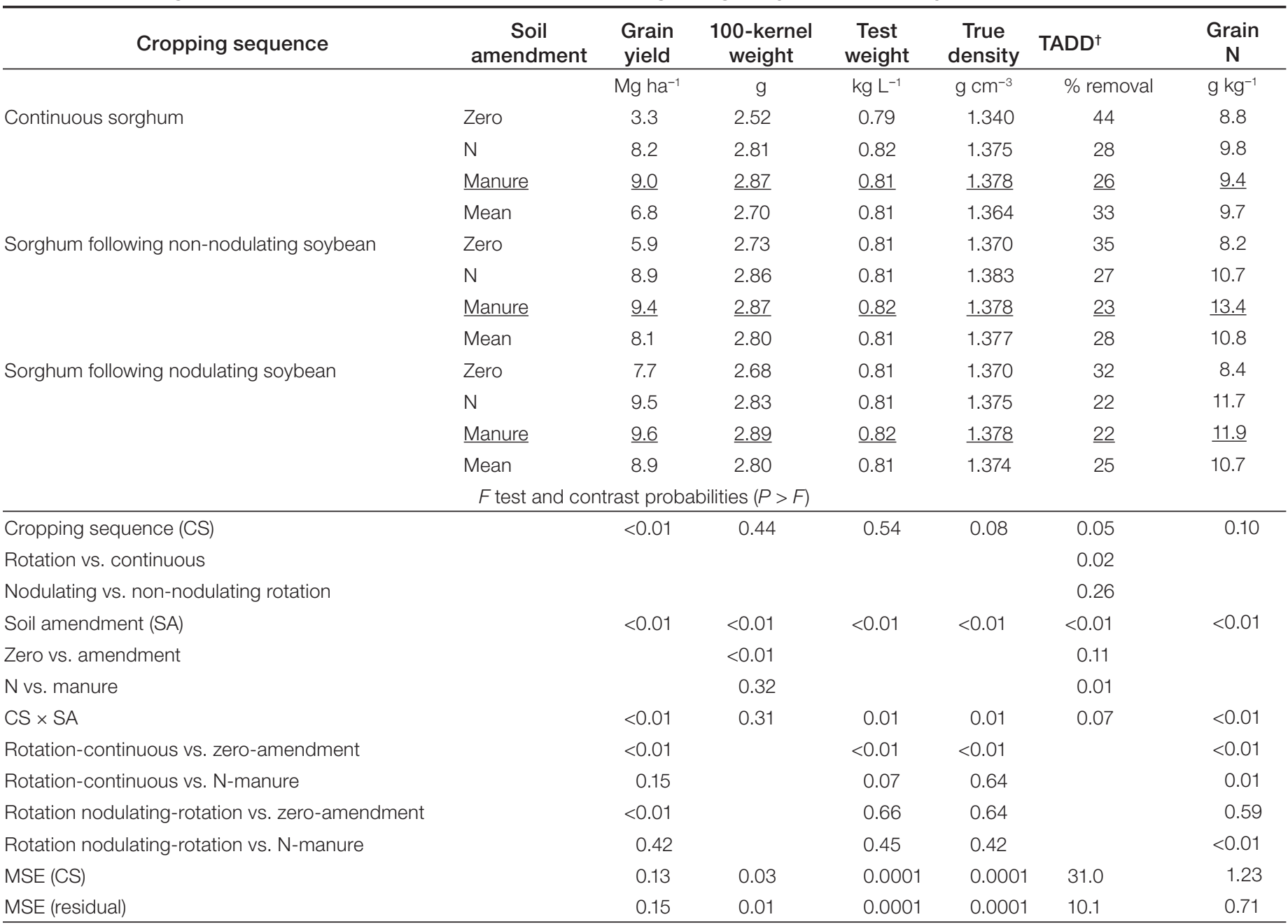

†TADD, tangential abrasive dehulling device.

TADD removal, indicating harder kernels. In 2003, both soil amendments reduced TADD removal (Table 1) while in 2004 manure application reduced TADD removal more than grain produced either with zero or $\mathrm{N}$ soil amendment application. Although no test was possible, grain produced in the drier, more stressful 2003 growing season had 4 to $6 \%$ higher TADD removal than for grain produced in 2004, consistent with finding of Johnson (2005).

Continuous sorghum grain without soil amendment produced the softest kernels based on test weight, true density, and TADD in both years, while sorghum grain produced following nodulating soybean and with manure application had the hardest kernels. Of the grain hardness tests used in this study, TADD removal was best able to detect treatment differences.

Although it was not possible to make a valid statistical test, grain $\mathrm{N}$ concentration responses varied across years for continuous sorghum (Tables 1 and 2). In both years the interaction contrast comparison indicated that soil amendment increased the grain $\mathrm{N}$ concentration more when rotated with soybean than for continuous sorghum. In both years the zero soil amendment had higher grain
$\mathrm{N}$ concentration than did the continuous sorghum, likely reflecting the documented inverse relationship between grain yield and $\mathrm{N}$ concentration (Mason and D'CrozMason, 2002). Sorghum rotated with soybean and with either $\mathrm{N}$ or manure application had the highest grain $\mathrm{N}$ concentration. In 2004, the interaction contrast comparison of rotation-continuous vs. $\mathrm{N}$-manure indicated that manure application increased grain $\mathrm{N}$ concentration over that $\mathrm{N}$ fertilizer for sorghum rotated with soybean, but not for continuous sorghum. Also in 2004, manure increased the grain $\mathrm{N}$ concentration of sorghum rotated with nonnodulating soybean, but not for sorghum rotated with nodulating soybean. Sorghum rotated with nodulating soybean had higher $\mathrm{N}$ concentration than with non-nodulating soybean with $\mathrm{N}$ application, while the opposite was true with manure application.

Previous research indicated that grain $\mathrm{N}$ concentration increases with $\mathrm{N}$ supply (Hanson et al., 1988; Kamoshita et al., 1998). The same result was found in this study, but the magnitude of the increase was least for continuous sorghum. Possible reasons could be reduced soil $\mathrm{NO}_{3}-\mathrm{N}$ content (Kaye et al., 2007), smaller root system of 
Table 3. Correlations of grain yield, grain $\mathrm{N}$, soil $\mathrm{NO}_{3}-\mathrm{N}$, and soil water with grain quality parameters in 2003.

\begin{tabular}{|c|c|c|c|c|c|}
\hline & \multicolumn{5}{|c|}{ Grain quality parameters } \\
\hline & $\begin{array}{c}\text { 100-kernel } \\
\text { weight }\end{array}$ & $\begin{array}{c}\text { Test } \\
\text { weight }\end{array}$ & $\begin{array}{c}\text { True } \\
\text { density }\end{array}$ & $\mathrm{TADD}^{\dagger}$ & $\begin{array}{c}\text { Grain N } \\
\text { concentration }\end{array}$ \\
\hline Yield & 0.20 & $0.74^{\star *}$ & $0.60^{\star \star}$ & $-0.69^{\star \star}$ & 0.26 \\
\hline Grain N concentration & $-0.35^{\star}$ & 0.17 & -0.05 & $-0.50^{\star \star}$ & - \\
\hline Soil $\mathrm{NO}_{3}-\mathrm{N}$ - planting & 0.24 & $0.41^{\star *}$ & $0.36^{\star}$ & $-0.58^{\star \star}$ & $0.48^{\star *}$ \\
\hline$-\mathrm{V} 6$ & 0.04 & $0.57^{\star \star}$ & $0.37^{\star}$ & $-0.72^{\star \star}$ & $0.60^{\star \star}$ \\
\hline - Anthesis & 0.19 & $0.39^{*}$ & 0.27 & $-0.49^{\star \star}$ & $0.44^{\star \star}$ \\
\hline - Physiological maturity & 0.21 & 0.16 & 0.09 & $-0.53^{\star \star}$ & $0.57^{\star \star}$ \\
\hline - Soil water-planting & -0.14 & -0.08 & -0.12 & 0.14 & -0.28 \\
\hline- V6 & $-0.56^{\star \star}$ & -0.13 & 0.16 & 0.16 & $-0.56^{\star \star}$ \\
\hline - Anthesis & 0.19 & $-0.64^{\star \star}$ & -0.32 & $0.68^{\star \star}$ & -0.33 \\
\hline - Physiological maturity & -0.05 & -0.24 & -0.10 & $0.47^{\star \star}$ & $-0.51^{\star \star}$ \\
\hline
\end{tabular}

${ }^{*} P \leq 0.05$.

${ }^{* *} P \leq 0.01$.

†TADD, tangential abrasive dehulling device.

Table 4. Correlations of grain yield, grain $\mathrm{N}$, soil $\mathrm{NO}_{3}-\mathrm{N}$, and soil water with grain quality parameters in 2004.

See Erratum with maize grain indicating that high $\mathrm{N}$ concentration produces harder kernels (Chandrashakar and Mazhar, 1999; Duarte et al., 2005; Kniep and Mason, 1989). Soil $\mathrm{NO}_{3}-\mathrm{N}$ content was positively correlated with grain $\mathrm{N}$, and negatively associated with TADD removal. Soil water content at anthesis and grain fill in both years was positively correlated with TADD removal. Thus, high soil $\mathrm{NO}_{3}-\mathrm{N}$ and low soil water resulted in harder sorghum kernels, consistent with the results of Kniep and Mason (1989) for maize. Increased hardness would be beneficial for dry milling and alkaline-cooked end-uses (Shandera et al., 1997; Johnson, 2005).

\section{Scanning Electron Microscopy of Sorghum Samples}

Qualitative observation of hard and soft kernels selected based on TADD, true density, test weight and grain $\mathrm{N}$ results were done with scanning electron microscopy. Hard kernels from manured plots with sorghum rotated with nodulating soybean had tightly packed starch granules well cemented by protein matrix (Fig. 1A). In contrast, soft kernels from continuous sorghum without soil amendment had starch granules loosely arranged with only partially cementing by protein matrix (Fig. 1B). This confirms cropping sequence and soil amendment influenced sorghum grain hardness and that hardness tests used in this study reflected visual differences in kernel structure, supporting results of Shull et al. (1990). continuous sorghum (Roder et al., 1989b) and/or different rate of nutrient cycling (Lemaire et al., 2004). Grain $\mathrm{N}$ concentration has also been shown to decrease with increasing sorghum grain yields when $\mathrm{N}$ supply is limited (Kamoshita et al., 1998), which was found for sorghum both years in the zero soil amendment plots in this study.

\section{Correlations}

Grain yield was positively associated with test weight and true density in both years, and negatively associated with TADD removal (Tables 3 and 4 ) indicating that production of hard sorghum kernels and high grain yield had similar production requirements. Grain N concentration was negatively associated with TADD removal, but not consistently associated with other hardness parameters measured. The TADD removal results support research

\section{Summary}

Crop rotation of grain sorghum with soybean combined with either manure or $\mathrm{N}$ fertilizer application have been recommended production practices for decades, but the basis for the enhanced yields from crop rotation are complex and not fully understood. This research indicated that biologically fixed $\mathrm{N}$ made only a 35 to $41 \%$ contribution to the enhanced yields produced with crop rotation. Rotation with soybean and soil amendment application increased grain $\mathrm{N}$ concentration and kernel hardness, which were associated with sorghum grain yield, soil $\mathrm{NO}_{3}-\mathrm{N}$, and soil water contents. The TADD removal test detected hardness differences well and was negatively associated with $\mathrm{N}$ concentration indicating that grain with high $\mathrm{N}$ concentration had harder kernels. As added-value food end-use opportunities for sorghum grain evolve, use 

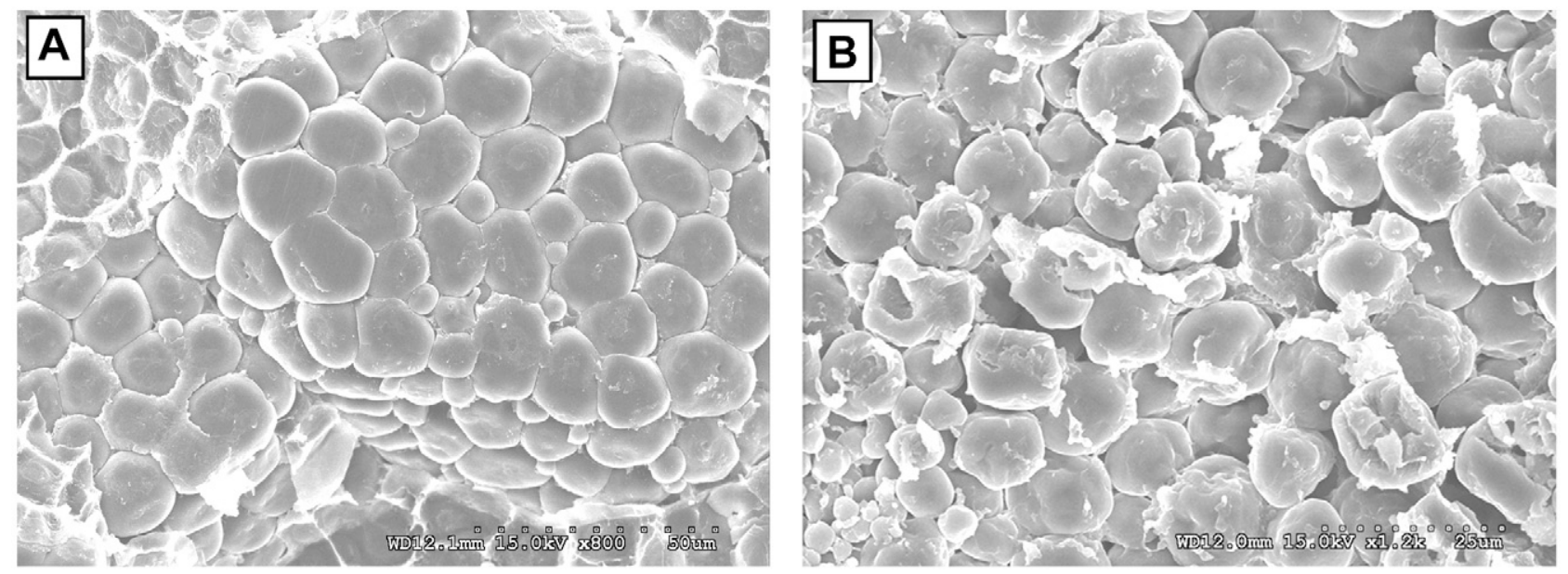

Figure 1. Scanning electron micrograph of (A) "hard" endosperm sorghum kernel produced in rotation with nodulating soybean and manure application, and (B) "soft" sorghum kernel produced in rotation with continuous sorghum and zero soil amendment.

of appropriate production practices such as crop rotation and soil amendment application along with cultivar selection will be important to produce grain with desirable quality attributes.

\section{References}

Bagayoko, M., S.C. Mason, and R.J. Sabata. 1992. Residual effects of cropping systems on soil nitrogen and grain sorghum yields. Agron. J. 83:862-868.

Bergerou, J.A., L.E. Gentry, M.B. David, and F.E. Below. 2004. Role of $\mathrm{N}_{2}$ fixation in the soybean $\mathrm{N}$ credit in maize production. Plant Soil 262:383-394.

Binder, D.L., A. Dobermann, D.H. Sander, and K.G. Cassman. 2002. Biosolids as nitrogen source for irrigated maize and rainfed sorghum. Soil Sci. Soc. Am. J. 66:531-543.

Buffo, R.A., C.L. Weller, and A.M. Parkhurst. 1998. Relationships among grain sorghum factors. Cereal Chem. 75(1):100-104.

Bundy, L.G. 2003. Nitrogen credits for low-yielding soybeans [Online]. Available at ipcm.wisc.edu/wcm/pdfs/2003/0325Soils1.html. Wisconsin Crop Manager: Fertility \& Soil, Soils 10(25).

Chandrashakar, A., and H. Mazhar. 1999. The biochemical basis and implications of grain strength in sorghum and maize. J. Cereal Sci. 30:193-207.

DeLoughery, R., and C. Wortmann. 2003. Calculating the value of manure for crop production. NebGuide G03-1519-A. Univ. of Nebraska Coop. Ext. Serv., Lincoln, NE

Dowdy, S., and S. Wearden. 1991. Hartley's test for homogeneity of variances. p. 348- 350. In Statistics for research. Wiley \& Sons, New York.

Duarte, A.P., S.C. Mason, D.S. Jackson, and J.C. Kiehl. 2005. Grain quality of Brazilian maize genotypes as influenced by nitrogen level. Crop Sci. 45:1958-1964.

Duodu, K.G., J.R.N. Taylor, P.S. Belton, and B.R. Hamaker. 2003. Factors affecting sorghum protein digestibility. J. Cereal Chem. 32:117-131.

Eastin, J.D. 1976. Temperature influence on sorghum yield, p. 1923. In H.D. Loden and D. Wilkinson (ed.) Proc. Ann. Corn Sorghum Conf., Washington, DC. 17-18 Jan. 1975. Publ. 31. Am. Seed Trade Assoc., Alexandria, VA.

Eghball, B. 2000. Nitrogen mineralization from field-applied beef cattle feedlot manure or compost. Soil Sci. Soc. Am. J. 64:2024-2030.

Ferguson, R.B. 2000. Grain and silage sorghum, p. 97-103. In R.B. Ferguson (ed.) Nutrient management for agronomic crops in Nebraska. Univ. of Nebraska Extension EC 01-155S. Coop. Ext. Ser., Lincoln, NE.

Gakale, L.P., and M.D. Clegg. 1987. Nitrogen from soybean for dryland sorghum. Agron. J. 79:1057-1061.

Gelderman, R.H., and D. Beegle. 1998. NO $-\mathrm{N}$ nitrogen. Recommended chemical soil test procedures for the North Central Region. Agric. Exp. Stn., Columbia, MO.

Gentry, L.E., F.E. Below, M.B. David, and J.A. Bergerou. 2001. Source of the soybean $\mathrm{N}$ credit in maize production. Plant Soil 236:175-184.

Hanson, R.G., J.A. Stecker, and S.R. Maledy. 1988. Effect of soybean rotation on the response of sorghum fertilizer nitrogen. J. Prod. Agric. 1:318-321.

Johnson, W.B. 2005. The influence of corn and sorghum characteristics on wet milling and nixtamalization performance. M.S. thesis. Univ. of Nebraska, Lincoln, NE.

Kamoshita, A., S. Fukai, R.C. Muchow, and M. Cooper. 1998. Genotypic variation for grain yield and grain nitrogen concentration among sorghum hybrids under different levels of nitrogen fertilizer and water supply. Aust. J. Agric. Res. 49:737-747.

Kasalu, H., S.C. Mason, and G. Ejeta. 1993. Effect of temperature on germination and seedling emergence of grain sorghum genotypes. Trop. Agric. (Trinidad) 70:368-371.

Kaye, N.M., S.C. Mason, and T.D. Galusha. 2007. Nodulating and non-nodulating soybean rotation influence on soil $\mathrm{NO}_{3}-$ $\mathrm{N}$ and water, and sorghum grain yield. Agron. J. In press.

Kniep, K.R., and S.C. Mason. 1989. Kernel breakage and density of normal and opaque-2 maize grain as influenced by irrigation and nitrogen. Crop Sci. 29:158-163.

Lemaire, G., S. Recous, and B. Maryet. 2004. Managing residues and nitrogen in intensive cropping systems. New understanding for efficient recovery by crops. In T. Fisher et al. (ed.) New Directions for a Diverse Planet, Proc. 4th Int. Crop Sci. Congr., Brisbane. 26 Sept.-1 Oct. 2004. Published online at www.cropscience.org.au (verified 11 Dec. 2006).

Littell, R.C., G.A. Milliken, W.W. Stroup, and R.D. Wolfinger. 1996. SAS system for mixed models. SAS Institute, Cary, NC. 
Maloney, T.S., K.G. Silveira, and E.S. Oplinger. 1999. Rotational vs. nitrogen-fixing influence of soybean on corn grain and silage yield and nitrogen use. J. Prod. Agric. 12:175-187.

Maranville, J.W., R.B. Clark, and W.M. Ross. 1980. Nitrogen efficiency in grain sorghum. J. Plant Nutr. 2:577-589.

Mason, S.C., and N.E. D'Croz-Mason. 2002. Agronomic practices influence maize grain quality. J. Prod. Agric. 5:75-91.

Maunder, B. 2005. Sorghum: The global grain of the future [Online]. Available at www.sorghumgrowers.com/Sorghum+101 (verified 19 Dec. 2006). National Grain Sorghum Producers Assoc., Lubbock, TX.

O'Brien, L. 1999. Genotype and environment effects on feed grain quality. Aust. J. Agric. Res. 50:703-720.

Oria, M.P., B.K. Hamaker, J.D. Axtell, and C. Huang. 2000. A highly digestible sorghum mutant cultivar exhibits a unique folded structure of endosprerm protein bodies. Proc. Natl. Acad. Sci. USA 97(10):5065-5070.

Padmore, J.M. 1990. Protein (crude) in animal feed-Dumas method, Method No 968.06. In K. Herlich (ed.) Official methods of analysis of the Association of Official Analytical Chemists, 15th ed. AOAC, Inc., Arlington, VA.

Peterson, T.A., and G.E. Varvel. 1989. Crop yield as affected by crop rotation and N rate. II. Sorghum. Agron. J. 81:727-731.

Roder, W., S.C. Mason, M.D. Clegg, and K.R. Kniep. 1989a. Yieldsoil water relationships in sorghum-soybean cropping systems with different fertilizer regimes. Agron. J. 81:470-475.

Roder, W., S.C. Mason, M.D. Clegg, and K.R. Kniep. 1989b. Crop root distribution as influenced by grain sorghum-soybean rotation and fertilization. Soil Sci. Soc. Am. J. 53:1464-1470.

Rooney, L.W., and F.R. Miller. 1982. Variation in the structure and kernel characteristics of sorghum, p. 143. In L. W. Rooney and D. S. Murty (ed.) Proc. Int. Symp. Sorghum Grain Quality. 28-31 Oct. 1981. ICRISAT, Patancheru, India Patancheru 502 324, Andhra Pradesh, India.

Sander, D.H., and K.D. Frank. 1980. Fertilizing grain sorghum. NebGuide G74-112. Univ. of Nebraska Coop. Ext. Serv., Lincoln, NE.

Shandera, D.L., D.S. Jackson, and B.E. Johnson. 1997. Quality factors impacting processing of maize dent hybrids. Maydica 42:281-289.

Shayo, N.B., H.S. Laswai, B.P.M. Tiisekwa, S.A.M. Nnko, A.B. Gidamis, and P. Njoki. 2001. Evaluation of nutritive value and functional qualities of sorghum subjected to different traditional processing methods. Int. J. Food Sci. Nutr. 52:117-126.

Shull, J.M., A. Chandrashekar, A.W. Kirleis, and G. Ejeta. 1990. Development of sorghum (Sorghum bicolor (L.) Moench) endosperm in varieties of varying hardness. Food Struct. 9:253-267.

Singh, R., and J.D. Axtell. 1973. High lysine mutant gene (hl) that improves protein and biological value of grain sorghum. Crop Sci. 13:535-539.

Sweeten, J.M., and A.C. Mathers. 1985. Improving soils with livestock manure. J. Soil Water Conserv. 40:206-210.

Tester, R.F., and J. Karkalas. 2001. The effects of environmental conditions on structural features and physico-chemical properties of starch. Starch 53:513-519.

Unger, P.W., and R.L. Baumhardt. 1999. Factors related to dryland grain sorghum yield increases: 1939 through 1997. Agron. J. 91:870-875.

Vanderlip, R.L. 1993. How a sorghum plant develops. Coop. Ext. Serv. Contrib. 1203, Kansas Agric. Exp. Stn., Manhattan, KS.

Varvel, G.E. 2000. Crop rotation and nitrogen effects on normalized grain yield in a long-term study. Agron. J. 92:938-941. 


\section{Published online July 30, 2007}

\section{ERRATUM}

\section{Crop Rotation and Soil Amendment Alters Sorghum Grain Quality}

Nanga Mady Kaye, Stephen C. Mason, David S. Jackson, and Tom D. Galusha

In Volume 47, Number 2, pp. 722-729, the figures listed in the fourth column of Table 4 were incorrect. The corrected Table 4 is listed below.

Table 4. Correlations of grain yield, grain $\mathrm{N}$, soil $\mathrm{NO}_{3}-\mathrm{N}$ and soil water with grain quality parameters in 2004 .

\begin{tabular}{|c|c|c|c|c|c|}
\hline & \multicolumn{5}{|c|}{ Grain Quality Parameters } \\
\hline & $\begin{array}{l}\text { 100-kernel } \\
\text { weight }\end{array}$ & $\begin{array}{c}\text { Test } \\
\text { weight }\end{array}$ & $\begin{array}{c}\text { True } \\
\text { density }\end{array}$ & $\begin{array}{c}\text { Tangential abrasive } \\
\text { dehulling device removal }\end{array}$ & $\begin{array}{c}\text { Grain N } \\
\text { concentration }\end{array}$ \\
\hline Yield & $0.69^{\star \star}$ & $0.57^{\star \star}$ & $0.77^{\star \star}$ & $-0.85^{\star \star}$ & $0.62^{\star \star}$ \\
\hline Grain N concentration & $0.48^{* \star}$ & 0.22 & $0.36^{\star}$ & $-0.62^{\star \star}$ & - \\
\hline Soil $\mathrm{NO}_{3}-\mathrm{N}$-planting & 0.22 & 0.17 & 0.31 & $-0.36^{*}$ & -0.07 \\
\hline$-\mathrm{V} 6$ & 0.26 & $0.43^{*}$ & 0.32 & $-0.57^{\star \star}$ & -0.26 \\
\hline -Anthesis & 0.26 & 0.18 & 0.23 & $-0.45^{\star \star}$ & $-0.38^{*}$ \\
\hline -Physiological maturity & 0.05 & 0.12 & 0.16 & -0.21 & $-0.43^{\star \star}$ \\
\hline Soil water-planting & -0.19 & -0.21 & $-0.51^{\star \star}$ & 0.20 & -0.07 \\
\hline$-\mathrm{V} 6$ & $-0.36^{\star}$ & -0.29 & $-0.42^{\star \star}$ & $0.46^{\star *}$ & -0.26 \\
\hline -Anthesis & $-0.59^{\star \star}$ & $-0.52^{\star \star}$ & $-0.69^{\star \star}$ & $0.73^{\star \star}$ & $-0.38^{*}$ \\
\hline -Physiological maturity & $-0.49^{\star \star}$ & $-0.48^{\star \star}$ & $-0.48^{\star \star}$ & $0.64^{\star \star}$ & $-0.43^{\star \star}$ \\
\hline
\end{tabular}

* Significant at $P \leq 0.05$.

** Significant at $P \leq 0.01$.

Published in Crop Sci 47:1764 (2007).

doi: 10.2135/cropsci2005.07.0346er

(C) Crop Science Society of America

677 S. Segoe Rd., Madison, WI 53711 USA

All rights reserved. No part of this periodical may be reproduced or transmitted in any form or by any means, electronic or mechanical, including photocopying, recording, or any information storage and retrieval system, without permission in writing from the publisher. Permission for printing and for reprinting the material contained herein has been obtained by the publisher. 